\section{Estuaries and Coasts}

December 2008, Volume 31, Number 6, Pages 1063-

1071

http://dx.doi.org/10.1007/s12237-008-9099-7

(c) 2008 Springer. Part of Springer Science+Business

Media

The original publication is available at http://www.springerlink.com
Archimer, archive institutionnelle de l'Ifremer http://www.ifremer.fr/docelec/

\title{
Interactions between Volatile Reduced Sulfur Compounds and Metals in the Seine Estuary (France)
}

\author{
Amandine Cozic $^{1,{ }^{*}}$, Eric Viollier ${ }^{2}$, Jean-François Chiffoleau ${ }^{3}$, Joël Knoery ${ }^{3}$ and Emmanuelle Rozuel ${ }^{3}$ \\ ${ }^{1}$ CNAM, Intechmer, BP324, 50103 Cherbourg, France \\ ${ }^{2}$ Laboratoire de Géochimie des Eaux, Université Paris Diderot \& IPGP, Case Postale 7052, 2, Place Jussieu, \\ 75251 Paris Cedex 05, France \\ ${ }^{3}$ Département DCN/BE, IFREMER, Rue de l'île d'Yeu, BP21105, 44311 Nantes, France \\ *: Corresponding author : A. Cozic, email address : amandine.cozic@gmail.com
}

\begin{abstract}
:
Concentrations of volatile hydrogen sulfide $\left(\mathrm{H}_{2} \mathrm{~S}\right)$, carbonyl sulfide (OCS), methane thiol (MeSH), dimethyl sulfide (DMS), and dimethyl disulfide (DMDS) in the Seine estuary (France) were investigated in spring 2005 using samples collected from the first meter beneath the surface. Levels of dissolved metals ( $\mathrm{Ag}, \mathrm{Cd}, \mathrm{Cu}, \mathrm{Zn}, \mathrm{Ni}, \mathrm{Co}, \mathrm{Pb}$ ), suspended particulate matter, and particular organic carbon were also assessed. Maximum concentrations were $0.80 \mathrm{nM}$ for $\mathrm{H}_{2} \mathrm{~S}, 0.64 \mathrm{nM}$ for OCS, $3.06 \mathrm{nM}$ for MeSH, $11.06 \mathrm{nM}$ for DMS, and $1.18 \mathrm{nM}$ for DMDS, and different features were observed for the five volatile reduced sulfur compounds (VRSCs). Experiments were conducted to determine silver-VRSC conditional stability constants. Major interactions were observed between $\mathrm{H}_{2} \mathrm{~S}$ and $\mathrm{Ag}$, which may partially account for the absence of volatile $\mathrm{H}_{2} \mathrm{~S}$ at the lowest salinities. OCS, MeSH, and DMS did not interact with $\mathrm{Ag}$, as revealed by their insignificant $K^{\prime}$ values. Variations in concentrations along the salinity gradient may be explained by the influence of phytoplanktonic compounds.
\end{abstract}

Keywords: Seine estuary - Volatile reduced sulfur compounds - Metal - Conditional stability constant 


\section{Introduction}

The Seine river rises on the Plateau of Langres in Burgundy and flows northwest into the English Channel at Le Havre, situated at the mouth of the 160-km long Seine estuary (Fig 1) whose upstream limit is marked by Poses Dam. The Rouen and Havre regions have become heavily industrialized over the last century (currently representing $40 \%$ of French industry) and are home to about $25 \%$ of the French population. The RNO (National Monitoring Network) previously revealed significant metal contamination in mussels along the Normandy coasts, with silver and cadmium concentrations several orders of magnitude higher than the lowest concentrations recorded in France during the same period (Chiffoleau et al. 2001 and 2005).

The SEINE AVAL scientific program was launched on the basis of this knowledge, to identify - among many other tasks - the origin of metals in the Seine river catchment are, evaluate their fluxes in the marine environment, measure their concentrations along the salinity gradient and model their biogeochemical behaviour in the estuary. Previous studies have already demonstrated the remobilization of particulate silver and particulate cadmium of freshwater origin in the mixing zone (Thouvenin et al. 2004) and hence their potential availability for marine organisms (Thouvenin et al. 2005).

Hydrogen sulfide $\left(\mathrm{H}_{2} \mathrm{~S}\right)$ is produced by the anaerobic decomposition of organic matter via sulfate reduction (Dyrssen and Kremling 1990) and is a constituent of anoxic marine environments at concentrations up to micromolar level. $\mathrm{H}_{2} \mathrm{~S}$ also exists in photic zones of oligotrophic to eutrophic waters (Luther and Tsamakis 1989; Cutter and Krahforst 1998). Walsh et al. (1994) additionally showed that phytoplankton species can produce hydrogen sulfide in oxic waters. A major source of $\mathrm{H}_{2} \mathrm{~S}$ in oceans appears to be the hydrolysis of carbonyl sulfide (Elliot et al. 1989). Carbonyl sulphide (OCS) is the most 
abundant and probably the most long-lived sulfur gas in the atmosphere (Ulshöfer and Andreae 1998). OCS production is based on two main processes: the photochemical degradation of dissolved organo-sulfur compounds (Zepp and Andreae 1994) and dark production (non-photochemical) from dissolved organo-sulfur compounds or sediment (Flock and Andreae 1996). Dimethyl sulphide (DMS, " $\mathrm{CH}_{3} \mathrm{SCH}_{3}$ "), methane thiol (MeSH, " $\mathrm{CH}_{3} \mathrm{SH}$ ") and dimethyl disulfide (DMDS, " $\mathrm{CH}_{3} \mathrm{SSCH}_{3}$ ") are synthesized from the same precursor: dimethylsulfoniopropionate (DMSP; Kiene and Taylor 1988; Tanzer and Heumann 1992). This molecule is released into the water column during phytoplankton degradation through grazing by zooplankton, senescence and cell leaking, and is subsequently converted into sulfur compounds by enzymatic cleavage or demethylation (Simo et al. 2002). Many metals (e.g., $\mathrm{Ag}, \mathrm{Cd}, \mathrm{Pb}$ ) and some transition metals (e.g., $\mathrm{Cu}, \mathrm{Co}, \mathrm{Zn}, \mathrm{Ni}$ ), such as hydrogen sulfide and thiols (Laglera and Van den Berg 2003), tend to interact and form complexes with soft bases and have affinities with sulfur compounds (Stumm and Morgan 1981). The conditional stability constant $\mathrm{K}^{\prime}$ for $\mathrm{Ag}(\mathrm{I})$ organosulfur complexes (e.g., thiols) is about $\log \mathrm{K}^{\prime}=13$ (Bell and Kramer 1999). Al-Farawati and Van den Berg (1999) determined the conditional stability constants of several metal-hydrogen sulfides in seawater $\mathrm{pH} 8$ at $25^{\circ} \mathrm{C}$ and revealed possible interactions between metal ions (e.g. $\left.\mathrm{Cu}^{2+}, \mathrm{Ag}^{+}, \mathrm{Cd}^{2+}\right)$ and $\mathrm{H}_{2} \mathrm{~S}$ in the marine environment. No data was available until now on interactions between other volatile reduced sulfur compounds (OCS, MeSH, DMS and DMDS) and metals, despite the fact that these compounds exhibit similar complexing properties. In this study, we experimentally determined conditional stability constants between VRSCs and one soft sphere metal $\mathrm{Ag}^{+}$- in the aim of pinpointing possible interactions between VRSCs and silver in aquatic environments. Silver was chosen as the prime candidate in view of its high 
contribution to Seine estuary contamination. We decided to use the Irving-Williams (1953) series, which classifies metals according to their affinities $\left(\mathrm{Co}^{2+}<\mathrm{Ni}^{2+}<\mathrm{Cu}^{2+}>\mathrm{Zn}^{2+}\right)$, coupled with knowledge on the conditional stability constants of $\mathrm{Ag}^{+}$, to assess possible interactions between VRSCs and metals in the Seine estuary. To achieve this, VRSCs and metal concentrations were measured along the salinity gradient during the SILVER-2 cruise, and an initial attempt was made to determine Silver-VRSC conditional stability constants.

\section{Materials and Methods}

\section{Sampling and in situ measurements}

The SILVER-2 cruise took place from the May 23 to June 1, 2005 on the R/V Thalia, equipped with a white room container. Sampling was done along the salinity gradient to determine variations in VRSCs and metal concentrations in the Seine estuary (Fig 1). During the 10-day cruise, each estuary station (from Caudebec to offshore of Le Havre) was sampled twice: once during spring tide (May 23-24) and once during neap tide (May 30-31). Marine coastal water samples (from Le Havre port to offshore of Dieppe) were collected from May 25-29 (Fig 1). One sample (named L station) was collected further offshore (Fig 1, black star) in order to assess VRSC and metal concentrations in a zone far removed from urban inputs.

Various additional parameters (conductivity, sea surface temperature SST, particulate organic carbon POC and suspended particulate matter SPM) were also determined to complete tour assessment of VRSC distribution along the salinity gradient. Conductivity and SST measurements were done using a polarographic probe and are available for all monitored stations (Chiffoleau et al. 2001). Suspended particulate matter (SPM) was 
collected by water sample filtration (one filter per sample, no replicates) through a preweighted membrane $\left(0.4-\mu \mathrm{m}\right.$ Nuclepore $\left.{ }^{\circledR}\right)$ under fixed pressure to avoid cell damage (Chiffoleau et al. 2001). Filtration of another aliquot of water samples through precombusted glass fiber $(0.7 \mu \mathrm{m}$ GF/F Whatman $)$ filters was performed on board. These filters were used to measure POC at the shore lab after individual storage in glass Petri dishes followed by immediate freezing and storage in the dark pending analysis (Chiffoleau et al. 2001). POC was analysed with a CHN autoanalyser (Carlo Erba model) after decarbonation by $\mathrm{HCl}$ vapour (Chiffoleau et al. 2001). Triplicate filters were used to improve POC measurement accuracy.

Water samples for metal analyses downstream from Tancarville bridge were collected using an all-Teflon ${ }^{\circledR}$ pump (Chiffoleau et al. 1994). Additional water samples were collected between Vieux Port and Poses, also using clean bottles. All samples were immediately filtered in the on-board laboratory container, using trace metal-cleaned preweighted filters $\left(0.4-\mu \mathrm{m}\right.$ Nuclepore ${ }^{\circledR}$; Chiffoleau et al. 1994). The filtered water subsamples were then preserved in acid-cleaned 250-ml polyethylene bottles and stored at $\mathrm{pH}<1.6$ pending further analysis (Chiffoleau et al. 1994).

\section{Volatile Reduced Sulfur Compound analysis} To avoid VRSC sample deterioration, analyses were carried out on board immediately after collection (less than 15 mins.). Water samples were collected using a clean polycarbonate bottle (with $\mathrm{HCl} 0.5 \mathrm{~N}$ ) dipped one meter beneath the sea surface. The subsample was immediately drawn into a clean syringe to avoid contact with the atmosphere and ensuing sample contamination. The sample syringes were stored in cool boxes pending duplicate analysis. 
The analytical method used was fully described by Cozic et al. (2008) and simultaneously determines the concentrations of five reduced, naturally volatile (free and labile) sulfur compounds in a water sample. This method is based on gas chromatography (GC CP-3800 Varian $^{\circledR}$ with a CP-PoraBond Q column), coupled with a purge and trap system. Briefly, the water sample $(15 \mathrm{ml})$ was injected into the stripping vessel using the syringe. Sulfur gases were then extracted from the liquid phase and swept into a cryogenic preconcentrated trap. Once extraction was complete, carrier gas (helium) was used to sweep the concentrated gases into the chromatographic column. Using this analytical method, up to 30 water samples were able to be analysed per day (less than 12 mins. per sample). Moreover, each sample was broken down into one filtered subsample $\left(0.45 \mu \mathrm{m}\right.$, Teflon ${ }^{\circledR}$ PTFE) and one unfiltered subsample, in order to

\section{Metal analyses}

Preconcentration by liquid/liquid extraction of the water samples (Danielsson et al., 1982) was performed to eliminate signal interference due to the salt matrix and concentrate the metals present in the sample. This technique is based on the production of metal complexes with a mixture of APDC and DDDC, their extraction by freon and subsequent destruction through acidification of the organic phase (Chiffoleau et al. 1994). An ICP-MS was used to determine dissolved metal concentrations (Ag, Cd, Pb, $\mathrm{Cu}, \mathrm{Co}, \mathrm{Zn}, \mathrm{Ni})$. Quality control and accuracy analysis were performed using certified international reference material from estuarine waters (SLEW-3 from the NRCC). The analytical results obtained for dissolved reference material systematically differed from certified values by less than $10 \%$, and reproducibility was generally better than $6 \%$ for 

pM for $\mathrm{Zn}, 100 \mathrm{pM}$ for $\mathrm{Cu}$ and $300 \mathrm{pM}$ for $\mathrm{Ni}$.

\section{Silver complexation by sulfur compounds}

Our experimental protocol was based on the mixing of a metal (silver) with a single volatile sulfur compound $\left(\mathrm{H}_{2} \mathrm{~S}\right.$, OCS, MeSH or DMS; DMDS standard not available) dissolved in deionized water to keep the chemical system as simple as possible. AlFarawati and Van den Berg (1999) previously demonstrated that the conditional stability constant between silver and $\mathrm{HS}^{-}$ions does not change significantly with salinity. $\mathrm{pH}$ was fixed at ca. 7.7 (with $\mathrm{KOH}$ added to the deionized water) for $\mathrm{H}_{2} \mathrm{~S}$ and DMS experiments and ca. 6.5 for OCS and MeSH.

Chemical speciation experiments were conducted as follows: an initial, pure solution

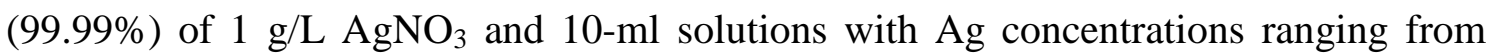
zero to 2 or $20 \mathrm{nM}$ were drawn in acid-cleaned $(\mathrm{HCl}, 0.5 \mathrm{~N})$ syringes. To avoid photodegradation, the syringes were stored in the dark at room temperature. Volatile reduced sulfur liquid solutions were then prepared (constant concentration, $2 \mathrm{nM}$ for $\mathrm{H}_{2} \mathrm{~S}$, OCS, MeSH and $20 \mathrm{nM}$ for DMS) using gaseous or liquid standards. Gaseous standards were from custom-made sulfur gas bottles (Scott Gas ${ }^{\circledR}$ ), with certified concentrations of $\mathrm{H}_{2} \mathrm{~S}(1.1 \pm 0.04 \mathrm{ppm})$ and DMS (1.1 $\left.\pm 0.01 \mathrm{ppm}\right)$. Solubility, depending on $\mathrm{pH}$, was $0.1 \mathrm{M} /$ atm for $\mathrm{H}_{2} \mathrm{~S}$ (Boffi et al. 2000) and $0.63 \mathrm{M} /$ atm for DMS (Barcellos da Rosa et al. 2003) in deionized water $\left(\mathrm{pH}<6,25^{\circ} \mathrm{C}\right)$. The quantity of gas to be injected into the acid-cleaned syringe was calculated according to Henry's law to obtain the equivalent targeted VRSC concentration in the liquid phase (deionized water). A calibrated-release permeation device (VICI-Metronics) was used for OCS. The air 
water; Elliot et al. 1989) to obtain a final 2-nM liquid OCS concentration in the syringe. A standard, liquid solution (21\% w/w, Aldrich) was diluted to acquire a final $2-20 \mathrm{nM}$ solution of methane thiol (MeSH). Finally, silver and VRSCs were mixed and an additional $10 \mathrm{ml}$ of sulfur-containing solution was added to each syringe containing a given silver concentration (e.g., $0 \mathrm{nM}, 0.25 \mathrm{nM}$ ). All syringes were shaken energetically for 2 minutes to mix the solutions and balance the liquid and gas phases, then stored in the dark again pending chromatographic analysis. Care was taken to systematically maintain the same "contact" time between VRSCs and silver prior to analysis. Final pH was ca. 7.7 for the $\mathrm{H}_{2} \mathrm{~S}$ and DMS solutions and ca. 6.5 for the OCS and MeSH solutions. Binding strength models were based on a multicomponent version of the single 1:1 complex formation mechanism, which is mathematically identical to the model of Langmuirian-type submonolayer adsorption (Ruzic 1996): whereby $\mathrm{S}$ is an individual binding site. In the following equations, silver is shown as $\mathrm{M}$ (for metal) and VRSC is shown as L (for ligand). The distribution of labile species (silver and VRSC) gives the following relationships in reference to equation (1):

$\mathrm{Mt}=\mathrm{M}^{\prime}+\mathrm{ML}, \mathrm{Lt}=\mathrm{L}^{\prime}+\mathrm{ML}$

whereby $\mathrm{Mt}$ and $\mathrm{Lt}$ represent the total concentrations of metal and ligand, and $\mathrm{M}^{\prime}$ and $\mathrm{L}^{\prime}$ represent concentrations of unreacted compounds, i.e. free active sites. The conditional stability constant is then defined as follows:

$\mathrm{K}^{\prime}=\mathrm{ML} /\left[\left(\mathrm{M}^{\prime}\right)\left(\mathrm{L}^{\prime}\right)\right]$

With a simple mathematical adjustment to equations (2) and (3), we obtain the following equation:

$$
\mathrm{K}^{\prime}=\left(\mathrm{Lt}-\mathrm{L}^{\prime}\right) /\left[\left(\mathrm{Mt} x \mathrm{~L}^{\prime}\right)-\mathrm{L}^{\prime}\left(\mathrm{Lt}-\mathrm{L}^{\prime}\right)\right]
$$


Using equation (4), which describes the relationship between the conditional stability constant $\mathrm{K}^{\prime}$, concentration of free sulfur active sites $\mathrm{L}^{\prime}$, total concentration of sulfur compound Lt and total concentration of silver Mt, we obtained a graphic representation of the conditional stability constants between silver and the test VRSCs. Equation (4) was then adjusted to a second-degree equation:

$$
\mathrm{L}^{\prime 2}+\left(1 / \mathrm{K}^{\prime}+\mathrm{Mt}-\mathrm{Lt}\right) \times \mathrm{L}^{\prime}-\mathrm{Lt} / \mathrm{K}^{\prime}=0
$$

The concentration of free sulfide active sites was determined for one conditional stability constant only, and for the selected total concentrations of silver and VRSCs (equation 5). The results of each speciation experiment will subsequently be compared with theoretical curves (for a fixed $\mathrm{K}^{\prime}$ ), to determine if significant interactions exist between silver and the test VRSCs. To facilitate discussion, conditional stability constants are represented by their $\log$ value $\left(\log \mathrm{K}^{\prime}\right)$.

\section{Results}

\section{Supporting parameters}

\section{Suspended particulate matter (SPM) distribution along the salinity gradient}

A comparison $\left(\chi^{2}\right.$ test, $\left.\mathrm{p}=0.05\right)$ of SPM distribution along the salinity gradient revealed clear differences (Fig 2) between the two estuary sampling periods, with highest values recorded during spring tide (May 23-24). However, highest SPM concentrations were systematically correlated with low salinity (below 10). This SPM profile may indicate the location of the maximum turbidity zone (MTZ), which is normally situated in the lowest salinities (salinity 0 to 5, Fig 2, Van den Berg 1993). The clear increase in SPM 
maximum zone (MEZ), where trace element mobilization and fluxes from sediments are stronger (Buggy and Tobin 2006).

\section{Particulate organic carbon (POC) distribution along the salinity gradient}

No significant variations in POC distribution $\left(\chi^{2}\right.$ test) were observed in the estuarine zone between the spring and neap tide sampling cruises (Fig 3). Similarly to SPM distribution, the highest values occurred with the lowest salinities, with up to $600 \mathrm{mg} / \mathrm{L}$ measured (Fig 3). This value increased in the mid estuarine zone, with $90.5 \pm 23.3 \mathrm{mg} / \mathrm{L}$ $(n=7)$ in the 14-20 salinity range. POC concentration decreased in the marine zone, with 18.1 $\pm 10.1 \mathrm{mg} / \mathrm{L}(\mathrm{n}=15)$. Relative standard deviation (RSD) for our measurements was $1.4 \%$ and $11.4 \%$ respectively.

\section{Distribution of VRSCs along the salinity gradient}

No significant differences were highlighted between filtered and unfiltered subsamples according to an $\chi^{2}$ test $(\mathrm{p}=0.05)$. Moreover, no significant differences $\left(\chi^{2}\right.$ test $)$ in VRSC concentrations were noted between the spring and neap tide cruises, although volatile sulfur compound distribution varied along the salinity gradient.

Hydrogen sulfide concentrations were below the limit of detection $(0.07 \mathrm{nM}$; Cozic et al. 2008) up to a salinity of 17.9. In the mid estuary zone, a clear increase in $\mathrm{H}_{2} \mathrm{~S}$ concentrations was observed, followed by a clear decrease at higher salinities (Fig 4A). Carbonyl sulfide concentrations were constant in the upper estuary and decreased slightly above salinity 18.7 (Fig 4B). Methane thiol, dimethyl sulfide and dimethyl disulfide showed similar profiles along the salinity gradient, i.e. a gradual increase to maximum value at mid-salinity range, followed by a decrease. This pattern was particularly marked for DMS and DMDS (Fig 4C, 4D, 4E). 


\section{Determination of Silver-VRSC conditional stability constants}

The $\mathrm{H}_{2} \mathrm{~S}$ conditional stability constant was determined by comparing experimental data with theoretical curves and gave a $\log \mathrm{K}^{\prime}$ value greater than 12 . This is similar to the results obtained by Al-Farawati and Van den Berg (1999) using sea water $\mathrm{pH}$, therefore supporting our method for determining VRSC conditional stability constants with a given metal. Other tested reduced sulfur compounds (OCS, MeSH and DMS) did not appear to have a strong affinity with silver. Free OCS (purgeable with helium) did not interact strongly with increasing silver concentrations, and a conditional stability constant $\mathrm{K}^{\prime}$ of between 0.1 and 0.01 - and hence a very low $\log \mathrm{K}^{\prime}(\approx 0)$ - was observed., The same trend was observed for MeSH, with a very low conditional stability constant notwithstanding the initial MeSH concentration $\left(\mathrm{K}^{\prime}\right.$ of about $0.05\left(\log \mathrm{K}^{\prime} \approx 0\right)$ ). An absence of interactions between DMS and $\mathrm{Ag}^{+}$was also shown with metal concentrations between zero and $20 \mathrm{nM}$. However, when silver concentrations were increased to $4 \mu \mathrm{M}$ (experimental value), a slight decrease (ca. 20\%) was observed in free DMS concentrations. We therefore concluded that the conditional stability constant $\mathrm{K}^{\prime}(\mathrm{Ag}) \mathrm{DMS}$ was $0.75 \times 10^{-4}\left(\log \mathrm{K}^{\prime} \approx 0\right)$, which is insignificant in view of observed silver concentrations. These preliminary experiments demonstrated that only $\mathrm{H}_{2} \mathrm{~S}$ appears to interact strongly with silver in aquatic environments. OCS and MeSH had a low affinity with silver and no interaction was observed with DMS.

\section{Metal distribution along the salinity gradient} lead $(\mathrm{Pb})$, copper $(\mathrm{Cu})$, cobalt $(\mathrm{Co})$, zinc $(\mathrm{Zn})$ and nickel $(\mathrm{Ni})$. Only silver concentrations 
metals were measured during the second cruise (Figure 5B-C). Silver and cadmium concentrations increased in the estuarine zone from zero to ca. 13-15 and decreased rapidly at the highest salinities (Fig 5A, 5B). Cobalt showed a relatively constant concentration $(1.1 \pm 0.2 \mathrm{nM}, \mathrm{n}=12)$ along the salinity gradient (Fig 5B). Nickel and copper distribution showed the same trend, with a slight decrease along the salinity gradient (Fig 5C). Zn concentrations clearly decreased along the salinity gradient (Fig 5C) after reaching a maximum near salinity 6.

\section{Discussion}

\section{Distribution of DMS, DMDS and MeSH along the salinity gradient}

Dimethyl sulfide, dimethyl disulfide and methane thiol concentrations clearly increased with salinity (Fig 4C-E). Phytoplankton density and POC distribution were positively correlated in the Seine estuary (Chiffoleau et al. 2001) and phytoplankton density was shown to be constant along the salinity gradient, with a relatively constant POC value from zero to salinity ca. 24 (Fig 3). Sciare et al. (2002) previously demonstrated that DMS increased with salinity in the Gironde estuary (France), correlated with the distribution of Phaeocystis and Dinophyceae, which are recognized as being high producers of DMSP (Liss et al. 1997). Lemaire et al. (2002) revealed the mid estuarine maximum zone to be highly reactive in terms of phytoplankton (organic matter) degradation. The distribution of DMS, DMDS and MeSH in the Seine river may therefore be accounted for by a shift in phytoplanktonic population from low DMS producers such as diatoms in the upstream estuary, to high DMS producers further downstream. Unfortunately, pigment data is unavailable for the SILVER-2 cruise. 
In comparison to other European estuaries (Sciare et al. 2002), DMS concentrations in the Seine river are very high, with maximum values greater than $10 \mathrm{nM}$ adjacent to salinity 25 (Fig 4D). The mean concentration $(8.2 \pm 4.5 \mathrm{nM} ; \mathrm{n}=52)$ measured in the Seine estuary is double that of the Rhine (Germany) and about ten times higher that of Gironde (France) (0.7 nM; Sciare et al. 2002). These results suggest a significant production of DMS in the estuarine plume, but cannot be further explained due to a lack of quantitative data on DMSP and phytoplankton species. In the marine zone (above 30salinity), DMS concentrations were similar to those determined by Turner et al. (1988) in sea water around mainland Britain, and by Walker et al. (2000) on the continental shelf. No other estuarine DMDS measurements have been conducted to date, hence making comparison with our data impossible. The relatively slow decrease in MeSH concentrations versus DMS and DMDS in marine waters may be due to consumption by bacterioplankton, which use MeSH for amino acid synthesis (Kiene et al. 2000). The constant MeSH concentrations observed above salinity 25 (Fig 4C) were put down to an increase in bacterial growth, which induces DMSP degradation in MeSH (Kiene and Taylor 1988). The clear decrease in DMS and DMDS concentrations in shelf waters may be due to dilution with upper estuarine waters, or mixing with older, oceanic water masses containing less DMS and DMDS than MeSH (Fig 4D-E). In conclusion, additional work clearly appears necessary to improve our understanding of DMS and DMDS increases in the plume versus the marine zone, and comprehend the high DMS values measured in the estuary.

\section{Distribution of OCS along the salinity gradient}


by Sciare et al. (2002) in the Rhine estuary (Germany), Watts (2000) in Yarmouth estuary (UK), and Cutter and Knoery (1993) in two estuaries in the eastern United States. The production of OCS in surface waters is thought to be controlled by photochemical processes, which depend on photosensitizer concentrations (Zepp and Andreae 1994), which in turn are related to phytoplankton concentrations (Kettle et al., 2001). The Seine estuary is a eutrophicated region, receiving significant organic inputs from the continent (Chiffoleau et al. 2001). The high OCS concentrations observed at low salinities could therefore be related to the microbial degradation of organic sulfur compounds (Andreae and Ferek 1992). The photo-destruction of methane thiol could be another source of carbonyl sulfide in the Seine river (Flock and Andreae 1996). In addition, light penetration generally decreases with rising SPM concentrations near salinity 14 (Smith and Baker 1979), therefore increasing OCS production by photodegradation. However, OCS release from sediment to overlying waters may be another major source in the estuarine environment, in particular in the mid estuarine zone (Zhang et al. 1998). The surface water distribution of OCS in the Seine river is hence likely to be influenced by sulfur gas fluxes from sediment, due to the estuary's data is available to estimate sedimentary OCS concentrations. Similarly to DMS and DMDS, the clear concentration decrease from salinity ca. 18 downwards could well be due to the mixing of high CDOM concentrations in estuarine waters and lower CDOM concentrations in seawater (less organisms). 


\section{Distribution of $\mathrm{H}_{2} \mathrm{~S}$ along the salinity gradient}

No volatile sulfides (free sulfide and labile metal-sulfide complexes) were observed at the lowest salinities (Fig 4A), whereas significant concentrations of carbonyl sulfide and others VRSCs were measured, suggesting the presence of major $\mathrm{H}_{2} \mathrm{~S}$ removal mechanisms. Oxidation induced by higher oxygen levels in the upper estuarine zone (Chiffoleau et al. 2001), complexation with particulate trace metals, or metal sulfide precipitation may explain the absence of free $\mathrm{H}_{2} \mathrm{~S}$ between salinity zero and 17.9. Rozan et al. (1999) similarly found no free sulfide in four southern New England rivers and suggested that this was due to metal sulfide complexes. Elliot et al. (1989) pointed out that the complexation of trace oceanic metals with bisulfide $\left(\mathrm{S}^{2-}\right)$ and sulfide ions $\left(\mathrm{HS}^{-}\right)$ should impact the amount of volatile $\mathrm{H}_{2} \mathrm{~S}$ in the water column. In view of its high conditional complexation constant with sulfide $\left(\log \mathrm{K}^{\prime}(\mathrm{Ag})=11.6\right.$; Al-Farawati and Van den Berg 1999), silver probably affects the percentage of free sulfide in the Seine estuary (Fig 4A). However, silver concentrations (Fig 5A) were very low compared to sulfide concentrations (Fig 4A) and the high interaction of silver with organic ligands (Luoma et al., 1995) and chloride suggests that silver cannot be responsible for the absence of free $\mathrm{HS}^{-}$in the upper estuarine zone. The high concentrations of copper found in the estuary (Fig 5C) and copper's high conditional complexation constant with bisulfide ions ( $\log \mathrm{K}^{\prime}=12.9$; Al Farawati and Van den Berg 1999) may also influence sulfide distribution in the estuary. Similarly to $\mathrm{H}_{2} \mathrm{~S}-\mathrm{Zn}$ complexes, $\mathrm{H}_{2} \mathrm{~S}-\mathrm{Cu}$ complexes are kinetically inert to dissociation (Luther et al. 1996); as a result, the absence of free sulfide ( $\mathrm{HS}^{-}$ions) in the upper estuarine zone may be due to strong interactions with copper. Cadmium, lead and cobalt metals do not appear to play a significant role in $\mathrm{H}_{2} \mathrm{~S}$ distribution in the Seine estuary in view of their weak interactions with sulfide (AlFarawati and Van den Berg 1999) and the low concentrations measured (Fig 5B). 
Although zinc and nickel concentrations were high in the upper estuarine zone (Fig 5C), their very low conditional complexation constants for bisulfide ions (Al-Farawati and Van den Berg 1999) mean they do not influence $\mathrm{H}_{2} \mathrm{~S}$ distribution. The presence of powerful metal "ligands" probably explains the absence of free sulfide in the upstream Seine. This theory has already been put forward by Cutter and Krahforst (1988), who showed that sulfide may impact the cycles of several trace metals via the formation of stable complexes at concentrations of less than $1 \mathrm{nM}$, hence causing free sulfide concentrations in the water column to decrease considerably.

The increased SPM concentrations in the mid estuary zone (Fig 2) coincided with an abrupt increase in hydrogen sulfide (Fig 4A), which may be linked to sedimentary sulfide releases (Luther at Tsamakis 1989). Sediments are capable of scavenging metals that interact with sulfide, hence increasing free sulfide concentrations in surface waters. As no differences were observed in $\mathrm{H}_{2} \mathrm{~S}$ concentrations in filtered and unfiltered samples, we concluded that SPM does not play a key role in $\mathrm{H}_{2} \mathrm{~S}$ distribution along the salinity gradient. Carbonyl sulfide hydrolysis may be highest in the mid estuarine maximum zone (MEZ), therefore explaining the presence of $\mathrm{H}_{2} \mathrm{~S}$ from salinity 18.9 upwards (Fig 4A-B). Moreover, the high degradation of organic matter (e.g. phytoplanktonic cells) observed in the MEZ may create anoxic microzones, leading to sulfate reduction and hydrogen sulfide production. Our current state of knowledge does not provide quantitative data on these $\mathrm{H}_{2} \mathrm{~S}$ sources. Similarly to the other VRSCs, the clear decrease in sulfide concentrations in the marine zone is related to fresh water dilution in the English Channel.

\section{Conclusion}

No significant interactions were shown between OCS and silver, MeSH and silver and DMS and silver. Variations in biogenic sulfur MeSH, DMS and DMDS compound 
distribution may be linked to phytoplankton speciation, with an increase in high DMSPproducers near salinity 20 . The significant OCS concentrations observed in the Seine estuary were related to various processes: dissolved organic sulfur compound photodegradation, methane thiol degradation and OCS diffusion from sediment (in the mid estuarine zone). Although silver may interact with bisulfide ions even at low concentrations, this did not explain the undetectable $\mathrm{H}_{2} \mathrm{~S}$ levels observed below salinity 14. The clear increase in sulfide concentrations at the highest salinities was related to an increase in sulfide sources (flux from sediments, hydrolysis of OCS and phytoplankton degradation), plus the presence of others metal complexation mechanisms (e.g. sedimentary scavenging). $\mathrm{H}_{2} \mathrm{~S}$ may be stabilized in the MEZ by oxygen depletion.

\section{Acknowledgments}

The SILVER 2 cruise was funded by the Seine Aval 3 program, which has been contributing to improving knowledge on the Seine estuary for several years. We would also like to thank the $\mathrm{R} / \mathrm{V}$ Thalia crew for their precious technical assistance during the 10-day cruise. 
Al-Farawati, R. and C.M.G.Van den Berg. 1999. Metal-Sulfide complexation in seawater. Mar. Chem. 63: 331-352.

Andreae, M.O. and R.J. Ferek. 1992. Photochemical production of carbonyl sulfide in seawater and its emission to the atmosphere. Global Biogeochem. Cy. 6: 175-183.

Barcellos da Rosa, M., W. Behnke and C. Zetzsch. 2003. Study of the heterogeneous reaction of $\mathrm{O}_{3}$ with $\mathrm{CH}_{3} \mathrm{SCH}_{3}$ using the wetted-wall flowtube technique. Atmos. Chem. Phys. 3: 1665-1673.

Bell, R.A. and J.R. Kramer. 1999. Structural chemistry and geochemistry of silversulfur compounds: critical review. Environ. Toxicol. Chem. 18: 9-22.

Boffi, A., M. Rizzi, F. .Monacelli and P. Ascenzi. 2000. Determination of $\mathrm{H}_{2} \mathrm{~S}$ solubility via the reaction with ferric hemoglobin I from the bivalve mollusk Lucina Pectina. Biochim. Biophys. Acta 1523: 206-208.

Buggy, C.J. and J.M. Tobin. 2006. Seasonal and spatial distributions of tributylin in surface sediment of the Tolka estuary, Dublin, Ireland. Env. Poll. 143: 294-303.

Chiffoleau, J.F., D. Cossa, D. Auger and I. Truquet. 1994. Trace metal distribution, partition and fluxes in the Seine estuary in low discharge regime. Mar. Chem. 47: 145-158.

Chiffoleau, J.F., D. Auger, E. Chartier, P. Michel, I. Truquet, A. Ficht, J.L. Gonzalez and L.A. Romana. 2001. Spatio-temporal changes in cadmium contamination in the Seine estuary (France). Estuaries 24: 1029-1040.

Chiffoleau, J.F., D. Auger, N. Roux, E. Rozuel and A. Santini. 2005. Distribution of silver in mussels and oysters along the french coasts: Data from the national monitoring program. Mar. Pollut. Bull. 50: 1713-1744.

Cozic, A., J. Radford-Knoery , B. Averty and E. Viollier. 2008. Simultaneous analysis of five volatile reduced sulfur compounds by purge and cryogenic trapping/gas chromatography separation in natural waters. Submitted.

Cutter, G. A. and C.F. Krahforst. 1988. Sulfide in Surface Waters of the Western Atlantic Ocean. Geophys. Res. Lett. 15 (12): 1393-1396.

Danielsson, L.-G., B. Magnusson, S. Westerlund and K. Zhang. 1982. Trace metal determinations in estuarine waters by electrothermal atomic absorption spectrometry after extraction of dithiocarbamate complexes into freon. Anal. Chim. Acta 144: 183-188. 
Dyrssen, D. and K. Kremling. 1990. Increasing hydrogen sulfide concentration and trace metal behavior in the anoxic Baltic waters. Mar. Chem. 30: 193-204.

450

451

452

453

454

455

456

457

458

459

460

461

462

463

464

465

466

467

468

469

470

471

472

473

474

475

476

477

478

479

480

481

482

Elliot, S., E. Lu and S. Rowland. 1989. Rates and mechanisms for the hydrolysis of OCS in natural waters. Environ. Sci. Technol. 23: 458-461.

Flock, O.R. and M.O. Andreae. 1996. Photochemical and non-photochemical formation and destruction of OCS and MeSH in ocean waters. Mar. Chem. 54: 11-26.

Irving, H. and R.J.P. Williams. 1953. The stability of transition-metal complexes. J. Chem. Soc. 637: 3192-3220.

Kettle, A.J., T.S. Rhee, M. Von Hobe, A. Poulton, J. Aiken and M.O. Andreae. 2001. Assessing the flux of volatile sulfur gases from the ocean to the atmosphere. J. Geophys. Res. 106: 12193-12209.

Kiene, R.P. and B.F. Taylor. 1988. Biotransformation of organosulfur compounds in sediments via 3-mercaptopropionates. Nature 332: 148-150.

Laglera, L.M. and C.M.G. Van den Berg. 2003. Copper complexation by thiols compounds in estuarine waters. Mar. Chem. 82: 71-89.

Lemaire, E., G. Abril, R. De Wit and H. Etcheber. 2002. Distribution of phytoplankton pigments in nine European estuaries and implications for an estuarine typology. Biogeochemistry 59: 52-23.

Liss, P.S., A.D. Hatton, G. Malin, P.D. Nightingale and S.M. Turner, 1997. Marine Sulfur emissions. Philos. T. Roy. Soc. 352: 159-169.

Luther, G.W. and E. Tsamakis. 1989. Concentration and form of dissolved sulfide in the oxic water column of the ocean. Mar. Chem. 27, 165-177.

Luther, G.W., D. Rickard, S.M. Theberge and A. Olroyd. 1996. Determination of metal (bi)sulfide stability constants of $\mathrm{Mn}^{2+}, \mathrm{Fe}^{2+}, \mathrm{Co}^{2+}, \mathrm{Ni}^{2+}, \mathrm{Cu}^{2+}$ and $\mathrm{Zn}^{2+}$ by voltammetric methods. Environ. Sci. Technol. 30: 671-679.

Ruzic, I. 1996. Trace metal complexation at heterogeneous binding sites in aquatic systems. Mar. Chem. 53: 1-15.

Rozan, T.F., B. Gaboury and G.W. Luther. 1999. Measuring Metal Sulfide complexes in oxic river waters with square wave voltammetry. Env. Sc. Tech. 33: 3021-3026.

Sciare, J., N. Mihalopoulos and B.C. Nguyen. 2002. Spatial and temporal variability of dissolved sulfur compounds in European estuaries. Biogeochem. 59: 121-141.

Simo, R., S.D. Archer, C. Pedros-Alios, L. Gilpin and C.E. Stelfox-Widdicombe. 2002. Coupled dynamics of dimethylsulfoniopropionate and dimethylsulfide cycling and the microbial food web in surface waters of the North Atlantic. Limnol. Oceanogr. 47: 53-61. 
Smith, R.C. and K.S. Baker. 1979. Penetration of uv-b and biologically effective doserates in natural waters. Photochem. Photobiol. 29: 311-323.

Stumm, W. and J. Morgan. 1981. Aquatic Chemistry. An introduction emphasizing chemical equilibria in natural waters. John Wiley and sons, New York. 780 pages.

Tanzer, D. and KG. Heumann. 1992. Gas chromatographic trace-level determination of volatile organic sulfides and selenides and of methyl iodide in Atlantic surface water. Inter. J. Environ. An. Ch. 48, 1: 17-31.

Thouvenin, B., B. Boutier, J.F. Chiffoleau, J.L. Gonzalez, L.A. Romana, D. Auger, B. Averty, E. Chartier, S. Crochet and I. Truquet. 2004. Contribution à l'étude de la dynamique et de la spéciation des contaminants. Rapport d'activité 2003. Programme Seine Aval 2. Thème Analyse des risques chimiques et microbiologiques.

Thouvenin, B., B. Boutier, J.F. Chiffoleau, J.L. Gonzalez, D. Cossa, D. Auger, B. Averty, E. Rozuel-Chartier, D. Menard, A. Santini and M. Olivier. 2005. Contribution à l'étude de la dynamique et de la spéciation des contaminants. Rapport d'activité 2004. Programme Seine Aval 2. Thème Morphodynamique, cycle des vases et contaminants associés.

Ulshöfer, V.S. and M.O. Andreae. 1998. Carbonyl Sulfide (COS) in the Surface Ocean and the Atmospheric COS budget. Aquat. Geochem. 3: 283-303.

Van den Berg, C.M.G. 1993. Complex formation and the chemistry of selected trace elements in estuaries. Estuaries 16: 512-520.

Walker, C.F., M.J. Harvey, S.J. Bury and F.H. Chang. 2000. Biological and physical controls on dissolved dimethyl sulfide over the north-eastern continental shelf of New Zealand. J. Sea Res. 43: 253-264.

Watts, S.F. 2000. The mass budget of carbonyl sulfide, dimethyl sulfide, carbon disulfide and hydrogen sulfide. Atmos. Environ. 34: 761-779.

Zepp, R.G. and M.O. Andreae. 1994. Factors affecting the production of OCS in seawater. Geophys. Res. Lett. 21: 2813-2816.

Zhang, L., R.S. Walsh and G.A. Cutter. 1998. Estuarine cycling of carbonyl sulfide: production and sea-air flux. Mar. Chem. 61: 127-142. 


\section{Figure captions}

Figure 1 - Study sites: the Seine estuary and English Channel coast. Marine stations were located between Le Havre port (salinity 26) to offshore of Dieppe (salinity 33).

Figure 2 - Distribution of Suspended Particulate Matter (SPM) along the salinity gradient from May 23 to June 1, 2005.

Figure 3 - Distribution of particulate organic carbon along the salinity gradient from May 23 to June 1, 2005.

Figure 4 - Distribution of VRSCs along the salinity gradient from May 23 to June 1, 2005. Estuarine stations had salinity in the 0.6-29.5 range. Marine stations had salinity in the 25.2-33.5 range. A, H2S ; B, OCS ; C, MeSH ; D, DMS ; E, DMDS. Analytical

Figure 5 - Distribution of dissolved metals along the salinity gradient from May 23 to June 1, 533 2005. A: dissolved silver; $\mathrm{B}: \mathrm{Cd}, \mathrm{Pb}$ and $\mathrm{Co}$; $\mathrm{C}: \mathrm{Zn}, \mathrm{Ni}$ and $\mathrm{Cu}$. 
Figure 1 -

Figure 2 -

Figure 3 -

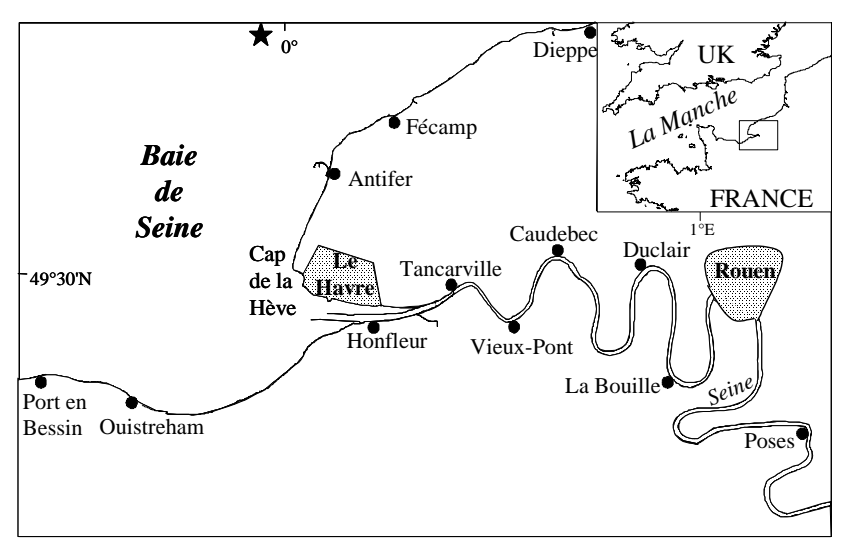

Suspended Particulate Matter (SPM) distribution along the salinity gradient

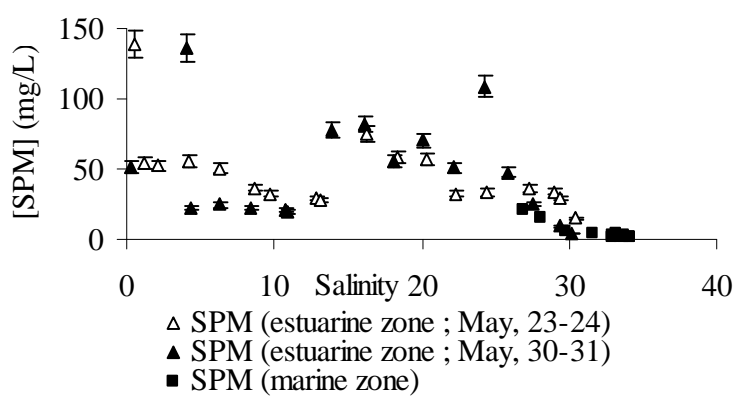

Particulate Organic Carbon (POC) distribution along the salinity gradient

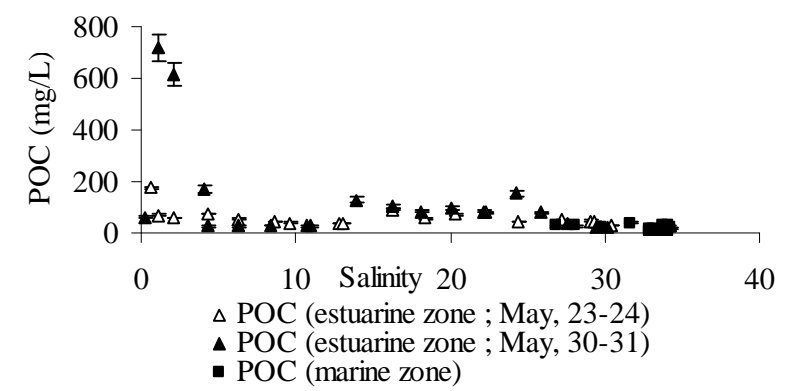


Figure 4 -

Distribution of hydrogen sulfide along the salinity gradient (from May 23 to June 1, 2005)

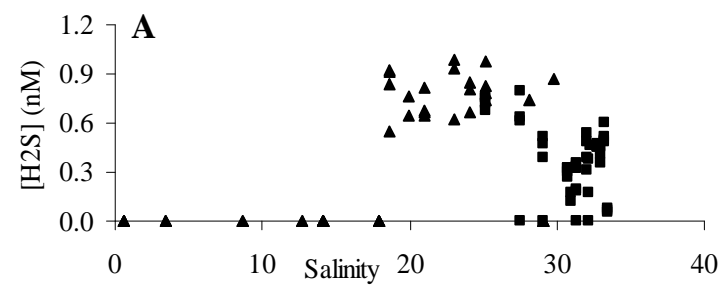

\ $\mathrm{H} 2 \mathrm{~S}$ (estuarine stations) - H2S (marine stations)

Distribution of methane thiol along the salinity gradient (from May 23 to June 1, 2005)

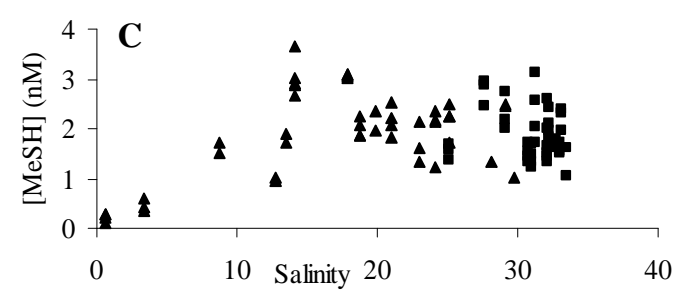

^ MeSH (estuarine stations) - MeSH (marine stations)

Distribution of dimethyl disulfide along the salinity gradient (from May 23 to June 1, 2005)

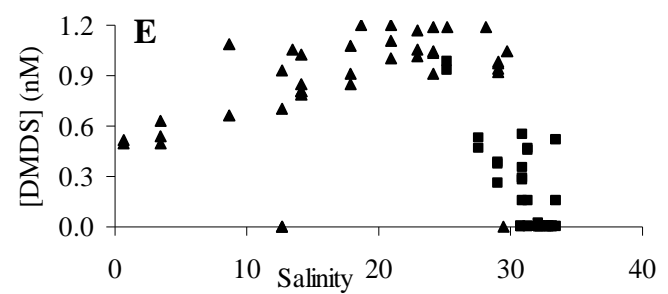

^ DMDS (estuarine stations) - DMDS (marine stations)
Distribution of carbonyl sulfide along the salinity gradient (from May 23 to June 1, 2005)

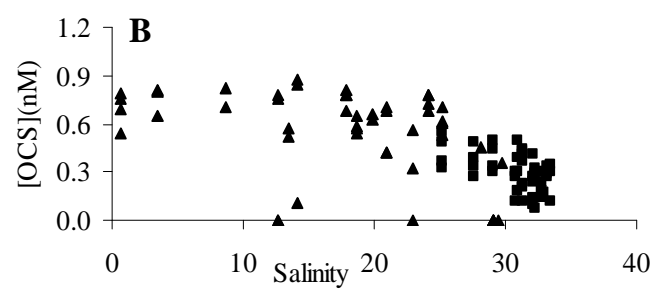

^ OCS (estuarine stations) - OCS (marine stations)

Distribution of dimethyl sulfide along the salinity gradient (from May 23 to June 1, 2005)

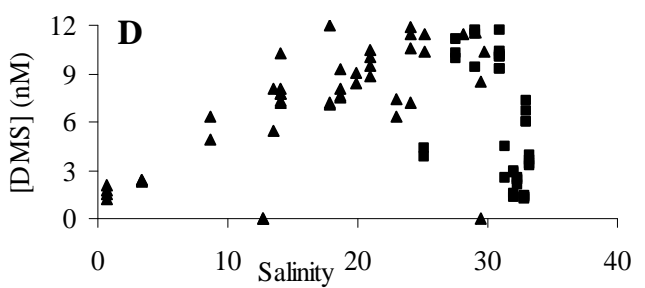

^ DMS (estuarine stations) - DMS (marine stations) 
Figure 5 -

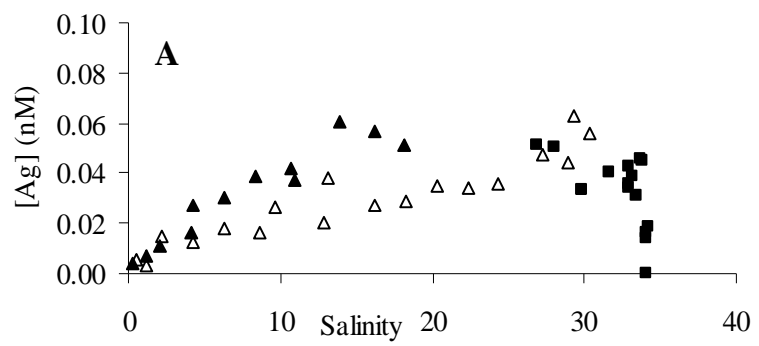

$\triangle \mathrm{Ag}$ (estuarine zone ; May,23-24) - Ag (marine zone)

^ Ag (estuarine zone ; May,30-31)
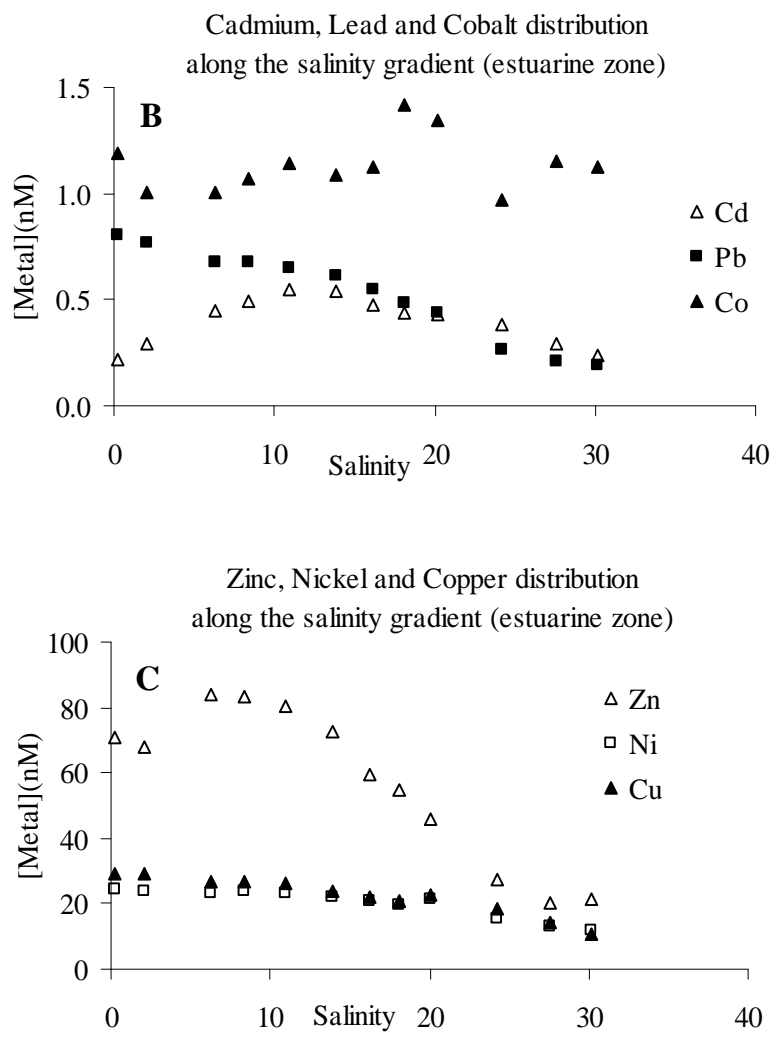

549

550

551 